\title{
Facile Synthesis of PVP-MnO $/$ CNT Composites as ORR Electrocatalyst for an Air-Cathode Microbial Fuel Cell
}

\author{
Huei Ruey Ong ${ }^{1}$, Chee Wai Woon ${ }^{2}$, Muhammad Sheraz Ahmad ${ }^{2}$, Abu Yousuf ${ }^{3}$, \\ Chin Kui Cheng ${ }^{2}$, Md. Maksudur Rahman Khan ${ }^{2, *}$ \\ ${ }^{1}$ Faculty of Engineering and Technology, DRB-HICOM University of Automotive Malaysia, 26607 \\ Pekan, Pahang, Malaysia. \\ ${ }^{2}$ Faculty of Chemical and Natural Resources Engineering, Universiti Malaysia Pahang, Lebuhraya Tun \\ Razak, 26300 Kuantan, Pahang, Malaysia. \\ ${ }^{3}$ Department of Chemical Engineering and Polymer Science, Shahjalal University of Science and \\ Technology, Sylhet-3114, Bangladesh \\ *E-mail: mrkhancep@yahoo.com
}

doi: $10.20964 / 2018.08 .05$

Received: 15 February 2018 / Accepted: 12 April 2018 / Published: 5 July 2018

The cathodic oxygen reduction reaction (ORR) is an influential step in fuel cells for the electrochemical energy conversion. Here we synthesized Polyvinylpyrrolidone incorporated carbon nanotube supported manganese dioxide (PVP-MnO $\mathrm{MnN}_{2} \mathrm{CNT}$ ) composite and used as ORR electrocatalyst for air-cathode microbial fuel cell (MFC). The physical and electrochemical characterization of PVP$\mathrm{MnO}_{2} / \mathrm{CNT}$ were performed by using Field Emission Scanning Electron Microscopy (FESEM), Energy Dispersive X-ray analysis (EDX), X-ray Diffraction analysis (XRD), Cyclic Voltammetry (CV) and Electrochemical Impedance Spectroscopy (EIS). The electrochemical characterization results showed that the PVP-MnO $\mathrm{MnN}_{2} / \mathrm{CNT}$ possessed the higher ORR catalytic activity with lower charge transfer resistance compared to $\mathrm{MnO}_{2}$ and $\mathrm{MnO}_{2} / \mathrm{CNT}$. The performance of the electrocatalysts as cathode was evaluated in air-cathode MFC and it was found that the MFC with $\mathrm{MnO}_{2}-\mathrm{PVP} / \mathrm{CNT}$ electrocatalyst generated a maximum power density of $1365.30 \mathrm{~mW} / \mathrm{m}^{3}$, which was higher than that of MFCs with $\mathrm{MnO}_{2} / \mathrm{CNT}$ catalyst $\left(1083.98 \mathrm{~mW} / \mathrm{m}^{3}\right), \mathrm{MnO}_{2}\left(540.91 \mathrm{~mW} / \mathrm{m}^{3}\right)$ and CNT (438.47 $\mathrm{mW} / \mathrm{m}^{3}$ ). Therefore, the viable synthetic strategy and proposed application of $\mathrm{PVP}-\mathrm{MnO}_{2} / \mathrm{CNT}$ will broaden up the reality of MFC for power generation.

Keywords: PVP-MnO $2 / \mathrm{CNT}$; Microbial Fuel Cell; Electrocatayst; Oxygen reduction reaction 
(C) 2018 The Authors. Published by ESG (www.electrochemsci.org). This article is an open access article distributed under the terms and conditions of the Creative Commons Attribution license (http://creativecommons.org/licenses/by/4.0/). 